\title{
KNOWLEDGE SHARING ON ONION CROPS AMONG THE FARMERS IN PERAMBALUR DISTRICT
}

\author{
J. NITHYA JAYASEELI ${ }^{1} \&$ T.DEVI ${ }^{2}$ \\ ${ }^{1}$ Assistant Professor (Computer Science), Roever Agriculture College, Perambalur, India \\ ${ }^{2}$ Professor and Head, Department of Computer Applications, Bharathiar University, Coimbatore, Tamil Nadu, India
}

This study was conducted in the onion producing area of Tamil Nadu state i.e. Perambalur district, to determine the risk and to produce the onion crops more effectively and efficiently to give more production quantity. The primary data collected from the onion farmers related to this production technology. The knowledge acquired from the experienced farmers regarding the source of Agriculture inputs from various departments, colleges, KVK's (Krishi Vigyan Kendra)and the information were shared to the unknown farmers in perambalur district to improve the production technologies of onion crops.
\end{abstract}

KEYWORDS: Questionnaire, Knowledge Sharing (KS), Economic, Production, Farming

Received: Jun 15, 2017; Accepted: Ju1 02, 2017; Published: Jul 05, 2017; Paper Id.: IJCSEITRAUG20171

\section{INTRODUCTION}

This study was concerned with the process of sharing knowledge on onion crops to improve the yield effectively and efficiently in Perambalur District. Sharing of information is knowledge management. The knowledge to be managed includes both explicit, document knowledge and tacit and subjective knowledge. The Perambalur District is one of the leading District in the state, in terms of productivity of many crops such as Maize (Rain fed), Cotton (Rain fed), pulses and small onion. Knowledge as 'Understanding gained through experience or study', it is the "known-how" or familiarity with how to do something, that enables a Person to perform a specialized task. The goal is to capture tacit knowledge from the expert farmers and encourage other formers to share and communicate knowledge; it is easier to determine which process is more effective (or) less effective to improve the production technologies of onion crops in Perambalur district. The main objectives are

- $\quad$ To design a Questionnaires for knowledge sharing on onion crops.

- To identify the source of knowledge among the farmers in onion production technologies.

- To know the socio economic status of the sample farmers.

- To analyse the knowledge utilization among the formers on onion crops.

\section{KNOWLEDGE SHARING}

The emergence of Information and Communication Technologies (ICT) in the last decade has opened new avenues in knowledge management that could play important roles in meeting the prevailing challenges related to sharing, exchanging and disseminating knowledge and technologies. Knowledge sharing, exchanging and dissemination are elements in a broader theme, which is knowledge management. The central purpose of 
knowledge management is to transform information and intellectual assets into enduring value. In many developing countries, small holder farmers have to grow their produce on limited land, with little access to vital inputs such as seed and fertiliser. They are often isolated from the information and training they require to maximise their yields and subsequently their incomes. This is why, these farmers have been coming together and forming co-operatives in recent years, to pool resources such as finance, technology, land and water, in order to work more effectively as a unit. There are abundant success stories about knowledge-sharing systems within co-operatives around the globe. Knowledge is power. Let us invest in building the capacities of those most in need, which will use this know-how to combat hunger.

\section{Design a Questionnaire for Farmers}

An abstracted description of work is that onion crop production technologies are to effectively improve in Perambalur District. This District comprises of their major agro-climate sub-Zones. Farmer requirements capture the intended behaviour of the onion crops during planting and harvesting. What is all the process that will do? The Questionnaires is designed for the farmers about their personal and educational status, land detail, crop details in their own hands to improve their productivity.

\begin{tabular}{|l|}
\hline *Personal Details: \\
\hline 1. Name of the Farmer: \\
\hline 2. Age of the: \\
\hline 3. Name of the Village: \\
\hline 4. Sex: \\
\hline 5. Occupation status of the farmer: \\
\hline 6. Educational status of the farmer: \\
\hline 7. Income status of the farmer's: \\
\hline *Land Details: \\
\hline 8. Total Land area: \\
\hline 9. Types of Land: \\
\hline *Crop Details: \\
\hline 10. Crop grown : \\
\hline \begin{tabular}{l}
$\mid$ S. No \\
\hline
\end{tabular} \\
\hline
\end{tabular}

Figure 1: Design Questionnaires for Knowledge Sharing on Onion Crops

\section{Response from the Farmers}

The respondents were shared by the other farmers, those who are known or unknown about the small onion crop technologies in all over the world, using knowledge management. Based on the analysis done in the knowledge acquisition from the farmers, it is studied that only particular aspects of the methodologies have been utilized with appropriate usage. Knowledge acquisition in onion crop production technologies can successfully increase crop innovation capability beyond that of competitors in the market. In order to get the onion crop details, process from planning to harvest from all levels of farmers during the interview/ Questionnaires, the following questions needed to be asked. This analysis illustrates how the 
onion crop production knowledge acquisition can affect the development of the crop to grow in a more efficient and effective way to improve the status of the farmers.

\section{PRODUCTION TECHNOLOGIES}

\section{Overall Production of Onion in Perambalur District}

The Perambalur District occupies an area of $1,752 \mathrm{~km} 2$ and had a population of 5, 65,223 with a sex-ratio of 1,003 female for every 1000 males. This district is a centrally located inland district of Tamilnadu, spread over 3, 69, 007 la. It is bounded by Cuddalore district in the north, Trichy district in south, Ariyalur district in east, Namakkal and Trichy district in rest.

Production is the conversion of inputs into output. The Perambalur district farmers implemented newly learnt technologies of drip irrigation, raised lead and better pest and disease control on three of seven acre plot to cultivate onion; they also are traditional of sowing on flat ground and using hybrid seeds fertilizers. Apart from the good yield, the new technologies helped him source labour cost for irrigation, fertilizer application and removal of weeds. The source of knowledge to the farmers is known during the interview process, only through nearby college, agriculture department and by their own heritage. The above mentioned technologies are used only by $65 \%$ of the farmers in this district. Remaining farmers are unknown about these technologies. The knowledge is gained through various modes. Among the family members, women have the knowledge essential for seed selection, because of this crop - related roles and tasks. Farmers' technology evaluation criteria are such as growth habit, yield, colour of grain, main use in the district processing and storage qualities, marketability (Farringdon and Martin, 1988) cost of sale, desirability for home consumption, compatibility with existing practices taste, nutritional value, cooking quality and resistance to pests (Van Veldhuizen et al, 1997). Varieties characteristics play a vital role in adoption of improved crop varieties. The source of knowledge is gained by participation in extension training, which enables farmers to get more information and improve their understanding about the available packages, which may in turn lead to a change in the knowledge attitude and behaviour. Moreover, the farmers in Perambalur District have practical experiences and field demonstration that have confirmed that technology adoption can be enhanced in a sustainable manner, by understanding the factors influencing the pattern.

\section{Source of Knowledge in Agricultural Innovation}

Knowledge management is concerned with ways of exchanging of knowledge among those, who can develop it and those who can use it. The lack of exchange of knowledge among and between farmers and those, who produce farmrelevant knowledge, has often been regarded as the key issue in pro-poor agricultural extension and development programmes.

The government and international donor agencies have focused on diffusing knowledge of farmers, who in turn were expected to gain from applying this knowledge in their production practices. People from nearby villages are unaware about the problems in farming communities related to market demand. Knowledge that rural and farming communities are typically interested in includes cultural management practices; new agricultural technologies, diagnostic information about plant and animal disease and soil related problems, market information on input sales (pieces, seller, buyers, and retailers) market demand and quality of products required for these markets and land records and government policies. The concerted efforts and practices used by organization and individuals to identify, create, accumulate, re-use apply and distribute knowledge are commonly labelled as knowledge management. 


\section{ECONOMIC STATUS}

\section{Seed Production}

Perambalur District is famous for the production of sambar onion and onion seeds. The seed produced here are supplied to various parts of Tamilnadu and Karnataka. Several cases of farmers committing suicide have been reported in different parts of the state over the last 10 years. It was noted that there were more suicide by farmers cultivating crops with a high level of cost of cultivation like cotton, onion, potato etc.....as compared to those who cultivated crops with low cost of production. The farmers in the Perambalur District come under this situation for the purchase of high cost inputs like seeds, fertilizers and pesticides. In many cases, these loans were obtained from informal money vendors or traders at high rates of interest. Failure of crops due to adverse seasonal conditions or uncontrolled pest attacks resulted in the inability of farmers to discharge the loans obtained by them. In India, about 65-70 percent of the population is dependent on agriculture for this life span. Agriculture plays a significant role in the overall socio-economic development of India. Socio Economic status is a combined statement of economic and social position of an entity compared in society. It often predicts the psychological and behavioural components. The onion farmers apart from engaging in onion enterprise also produced other crops such as tomatoes, potatoes, maize, rice etc...

\section{Farmer's Risk Attitude and Farm Production Organization}

Sequential marketing, forward contracting, hedging and co-operative marketing are some of the strategies that can reduce market risks. Sequential marketing involves gradual release into the market of the commodity for sale instead of dumping the entire quantity at once to depress market price.

Dispatch of seed onions to other centres after sorting and segregation has commenced in their villages. A large numbers of farm works from Esanai and nearby villages are engaged in their work at present traders from Coimbatore, Rasipuram and Trippur have got their stock of seed onions. Farmers of Perambalur District have got orders from Mysore and neighbouring areas and the stock will be dispatched to them shortly. The main problem faced by the small farmer is rainfall marketing agencies. The investment for the onion during the first stage is more compared to the end stage in marketing, which is totally different, and they always maintain the marketing loss. The farmers from Esanai were explained their economic problem during the Questionnaire administration very seriously, they sell the onions seeds $1 \mathrm{~kg}$ for Rs. 15 on Monday to the whole sale and the next day they go to market to buy the seeds $1 \mathrm{~kg}$ for Rs.30. The middle man plays a very important role in economic attitude of the Perambalur District. Generally, onion farmers were very poor in the use of risk management strategies due largely to unavailability of the strategies, despite the ranking of marketing, and the most important thing is, formers did not use any of the knowledge utilization methods to eliminate or reduce the risks.

\section{KNOWLEDGE UTILIZATION}

\section{Strengtheners \&Weakness}

The farmers in the district are very progressive and innovative in adopting moderns' technologies and crop varieties. It is a leading district in terms of productivity of many crops. This district has a good local market for its agricultural commodities, especially fruits and vegetables, since it is located on the National Highways connecting Chennai and Trichy. The Weaknesses are:

- How rainfall is and their heavy dependence on north-eastern monsoon. 
- Fragmented holdings and more than 75 percent of the farmers are marginal and small holders.

- $\quad$ Limited availability of ground water.

\section{Opportunities}

- To promote new crop varieties and new technologies such as precision farming and system of rice intensification.

- To introduce water saving technologies under canal irrigation system, especially in the irrigated agricultural system in view of the huge seepage loss of water during flood irrigation of the fields.

- Dry land agriculture has a good potential in this district with appropriate combination of crops, tree crops and livestock enterprises.

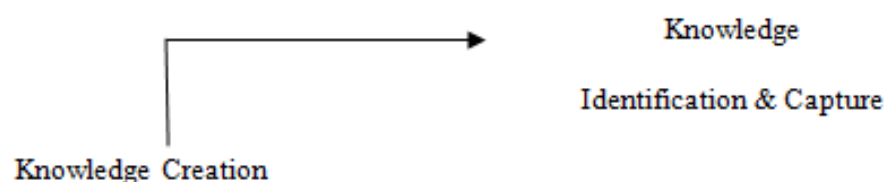

Knowledge Creation

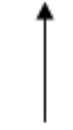

Knowledge

Application and Use
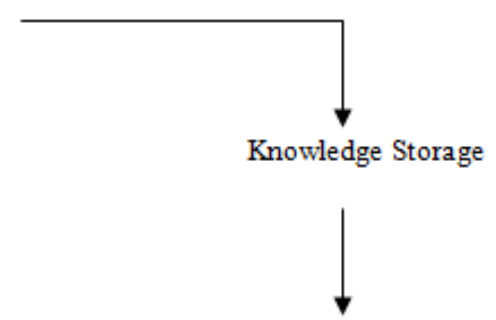

Knowledge

Sharing

Figure 2: Knowledge Sharing Process

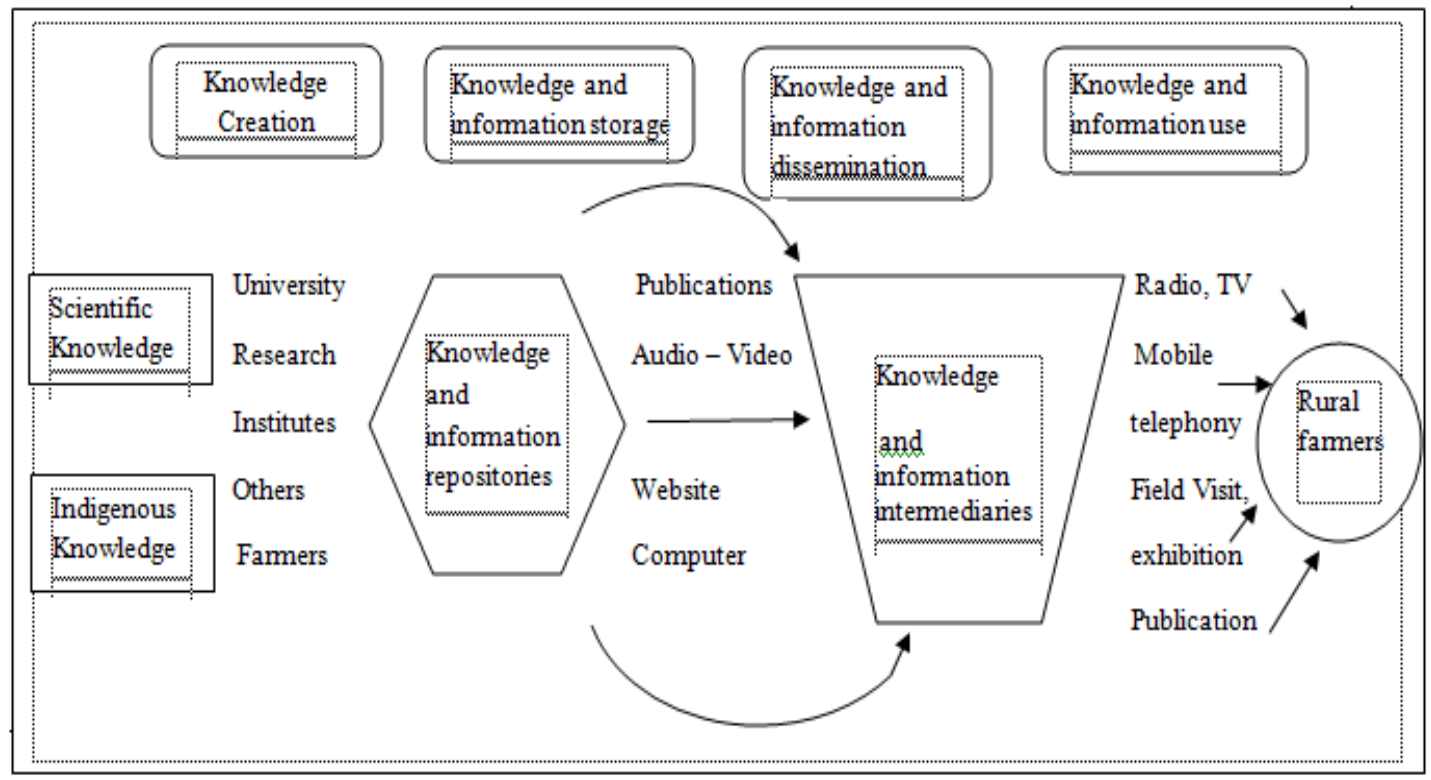

Figure 3: Knowledge Sharing Process

Agricultural information and knowledge created from these sources is stored in various forms before it is disseminated for use. The main repositories of such knowledge include publications, audio visuals, and websites. The 
stored knowledge and information is then disseminated to users such as rural farmers, through intermediaries notably during trainings, field visit, exhibition, publications, and using traditional forms of ICT, modern forms of ICT and others. Figure 3, shows the flow of agricultural knowledge and information from creation to end use. Figure 3, Tools of knowledge and information management in agriculture. Effective knowledge management is achieved when the right knowledge and information is delivered t to the right person at the right time in a user friendly and accessible manner that helps the recipients to perform their jobs efficiently. The outcome of effective knowledge management includes improved productivity and performance of the agricultural sector. The knowledge is utilized through various components by the farmers to improve the production technologies of onions crops to get more income effectively. The simple produce is followed by the small farmers by this heritage. The basic knowledge for the farmers to cultivate the onion crops are

- Environmental requirements

- Methods of onion seed production

- Bulb to seed method of onion seed production

- Method bulb production

- $\quad$ Nursery management

Nursery site, seed treatment, seed rate, spacing, fertilizer, bed covering / mulching, grease curve removal, bad irrigation ,pest control are the basic steps to planting the onion crops.

\section{CONCLUSIONS}

This study reports knowledge shared to the onion farmers using knowledge management. The outcome of the study using various farmers using our production technologies is reported. It highlights about developing onion seed/ seedling technologies by the onion crops farmers in perambalur district. Structured questionnaire to collect the knowledge on onion crops yielding processes has been designed, and the development is, most of the farmers are unaware of onion crop technologies and rebrand data, and they nontrade only by their hut age farming.

\section{REFERENCES}

1. Kasele Sydney Steven,(2004).Knowledge sharing and communication tools for dialogue issues on productivity of water in agriculture, International Journal of Innovation in Engineering \& Managment,3(3),102-103

2. Vincent Soulignac, Jean-Louis Ermine,(2012).A Knowledge management system for Exchanging and creating knowledge in organic farming, Electronic journal of Knowledge Management Volume 10 Issues( 2) 2012.

3. Frank Hartwich, Mario Monger Perez, Knowledge Management for agricultural Innovation: Lessons for networking efforts in the Bolivian Agricultural Technology System.

4. Paul G.H Engrel, Knowledge management in agriculture: Building upon Diversity. The International Journal of knowledge Transfer, Full 1990, Vol.3.No.3.PP.28-35. 